\title{
Obituary
}

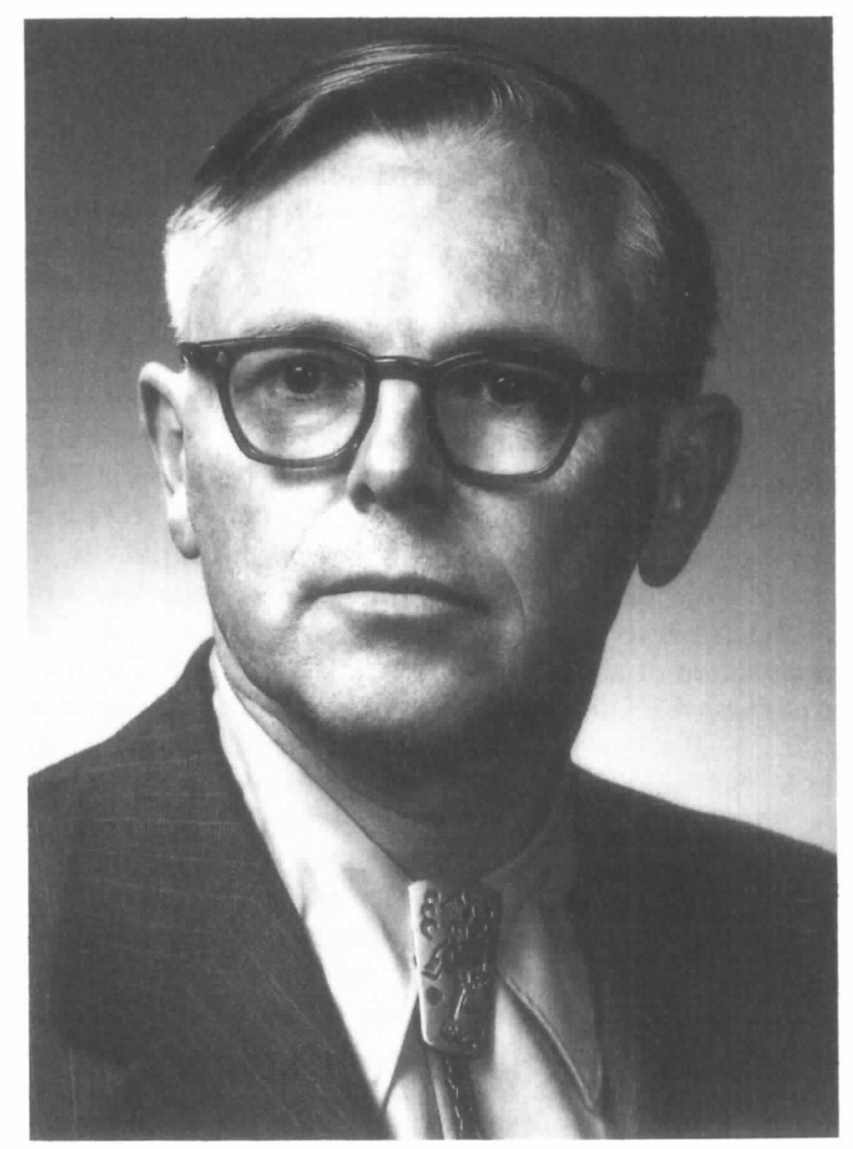

\section{David Powell Shoemaker 1920-1995}

David Powell Shoemaker, who is known to most of the readers of this journal through his many services and contributions to crystallography, died during the course of his regular hemodialysis in Albany, Oregon, on 24 August 1995. The treatment had sustained him well for six years. He is survived by his wife, Clara Brink Shoemaker, son Robert, daughter-in-law Wendy and grandson Roland.

David was born in Kooskia, Idaho, May 12, 1920, the first in a family of five brothers. He attended Reed College in Portland (BA 1942) and Caltech (PhD 1947), following which he was awarded a Guggenheim Fellowship (at 27, one of the youngest so honored). His fellowship year was spent mainly at the Institute for Theoretical Physics in Copenhagen, but partly in Oxford during Linus Pauling's tenure there of the Eastman Professorship. He returned to Caltech as Senior Research Fellow (1948-1951) before going on to MIT. Provoked by the increasing pollution of the Eastern megalopolis and attracted by the opportunity of returning West, he moved to Corvallis in 1970 as Chairman of the Chemistry Department of Oregon State University. He retired there in 1984.

At Caltech, David immediately demonstrated a remarkable ability to work imaginatively, with seemingly automatic supreme organization and with great effect on any problem he was given, first in the context of wartime research and later in crystallography. His thesis (I. An Attempt to Prepare Antibodies to Histamine In Vitro, II. An Investigation of a Possible Method for Preparing 
Large Single Crystals of Aluminum Orthophosphate, III. A. An Investigation of the Space-Group and Lattice Constants of DL-Serine, B. An Investigation of the Crystal Structure of L-Threonine) records two investigations he made during the war, one for Carl Niemann and one for Pauling, but he worked on other war projects also. An article on the design and use of a special viscometer [D. P. Shoemaker, Earl Hoerger, R. M. Noyes \& R. H. Blaker (1947). Anal. Chem. 19, 131] was one product of his work on Pauling and Corey's big study of the 'stability of double-base propellants'. Another was the electron-diffraction determinations he made of the structures of 16 molecules, which appeared in a compilation [P. W. Allen \& L. E. Sutton (1949). Acta Cryst. 3, 46-72; VS is now astonished to find them attributed to V. Schomaker, as privately communicated by L. Pauling and V. Schomaker]. The threonine study was notable for other reasons also, but we want to dwell on how David in his visual estimation of the intensities systematically compared all the reflections seen on complete sets of multiple-film Weissenbergs for all three orthorhombic axes. He also gave estimates of the errors to be feared. These correspond to a standard deviation of about $8.5 \%$ in an intensity measurement or perhaps $4.3 \%$ for an $|F|$, hardly in agreement with the $11.2 \% R$ value reported [D. P. Shoemaker, J. Donohue, V. Schomaker \& R. B. Corey (1950). J. Am. Chem. Soc. 72, 2328-2349] for the determination, which concluded with a single cycle of full-matrix refinement, with fixed scale factor and fixed equal isotropic $B$ 's for all the atoms, that required about $100 \mathrm{~h}$ of IBM 602 time. More recently, full-matrix leastsquares refinement of the structure with Hughes weights, isotropic freely adjusted $\mathrm{H}$ atoms and anisotropic $\mathrm{C}$, $\mathrm{N}$ and $\mathrm{O}$ atoms has led after many cycles (and a few minutes of computer time) to $R=4.4 \%$. It seems that David's visual intensity estimates for threonine, 49 years ago, were as good as he said they were, and that the authors SDSC simply failed to account for them because their computing methods and model were far from adequate.

Back in Pasadena after his year abroad, David helped complete the arduous work on threonine and solved the structure of DL-serine [D. P. Shoemaker, R. E. Barieau, J. Donohue \& C.-S. Lu (1953). Acta Cryst. 6, 241-256], which had previously stumped the laboratory. He also began what became his main research career, on the structures of complex transition-metal phases, with the discovery of the $\sigma$-phase structure with 'his' (officially Pauling's) student B. Gunnar Bergman. With Clara and their associates at MIT, and later at Oregon State, he continued to work out and publish a long list of related structures. These transition-metal alloy structures with only tetrahedral interstices ('tetrahedrally close packed') later became important as possible storage materials for hydrogen, and a collaboration was established with the Crystallographic Laboratory of E. F. Bertaut in
Grenoble. Structural principles, such as local approximate icosahedral symmetry and repetition of icosahedral orientation through linking of icosahedra, became of interest with the discovery of quasicrystals. Early in his MIT career, David also began notably productive work on the structures of zeolites, which included derivations-discoveries of the structures of the commercially most important zeolites (A and $\mathrm{X} / \mathrm{Y}$-Faujasite). He also found time to write (with Carl W. Garland, Jeffrey I. Steinfeld and later Joseph W. Nibler) a widely used laboratory text Experiments in Physical Chemistry, now in its sixth edition. For the book Crystallography in North America, published in 1983 by the American Crystallographic Association, David wrote an engaging account of his MIT days that we recommend to all for further details. One charming paragraph, however, needs quoting.

'The decisive occurrence in the formation of my research group [at MIT] and in getting the new program going was the arrival in 1953 of Clara Brink, Ph.D. Leiden 1950, who had worked in the Laboratories of A. E. van Arkel, J. M. Bijvoet, Dorothy Hodgkin (on vitamin $\mathrm{B}_{12}$ ), and Caroline MacGillavry. Jack Dunitz, after meeting Clara in Holland and learning of her plans to come to my laboratory, is reported to have said to mutual acquaintances: "I have just met Dave Shoemaker's future wife!" Well it took two years for Dave Shoemaker to get the picture, but Jack's perceptivity was vindicated when the wedding took place in 1955.'

David came to Oregon State in 1970 as chairman of the Chemistry Department, a position he held until 1981. During this time he had primary responsibility for the department's building program, which included the construction of a new building designed for chemistry laboratory teaching and a complete renovation of the old building (Gilbert Hall) aimed at improvement of office and research facilities. Several outstanding new faculty were appointed during his chairmanship. David's administrative duties necessarily slowed, but by no means stopped, his research and other professional activity. With Clara he remained active in his alloy and zeolite work, and he continued to carry out important assignments on behalf of national and world crystallography. After leaving the chairmanship in 1981 he taught undergraduate laboratory chemistry until his retirement in 1984.

Among David's professional services were 15 years on the USA National Committee for Crystallography, including three years as Secretary-Treasurer and three as Chairman (1967-69); Organizing Chairman of the Eighth International Congress and General Assembly of the International Union of Crystallography (1969); three times delegate to the General Assemblies of the International Union of Crystallography; President of the American Crystallographic Association (1970); member of the Executive Committee of the International Union of 
Crystallography (1972-78); regional Co-editor of Acta Crystallographica; and member of several commissions and panels. In addition to the American Crystallographic Association, David was a member of the American Chemical Society, the Federation of American Scientists, the American Academy of Arts and Sciences (Fellow) and the American Association for the Advancement of Science (Fellow).

This account would not be complete without mention of David's personal attributes. He was, first of all, devoted to his family and took great pleasure in Robert and his accomplishments, and later the birth of his grandson. He never forgot his Danish experience, and together with the rest of us took delight in the celebration of Midsummer's Eve, which we did as a group on more than one occasion on a local mountain top after his and Clara's arrival in Oregon. But perhaps most of all we will remember his courage, for despite his obviously declining health he always projected an air of good cheer and unfailing optimism. His interest in everything was unflagging and he continued to discuss scientific problems with spirit and his customary insight until the very end. As a fitting tribute to his memory, Clara has established the 'D. P. Shoemaker Memorial Graduate Fellowship', which will be used to honor outstanding graduate students in the Chemistry Department of Oregon State University.

VERNER SCHOMAKER KENNETH HEDBERG 